\title{
Application of GIS for Mapping Rainwater-Harvesting Potential: Case Study Wollert, Victoria
}

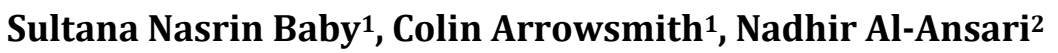 \\ ${ }^{1}$ School of Mathematical and Geospatial Sciences, Royal Melbourne Institute of Technology, RMIT University, Melbourne, Australia \\ ${ }^{2}$ Lulea University of Technology, Lulea, Sweden \\ Email: nadhir.alansari@ltu.se
}

How to cite this paper: Baby, S.N., Arrowsmith, C. and Al-Ansari, N. (2019) Application of GIS for Mapping Rainwater-Harvesting Potential: Case Study Wollert, Victoria. Engineering, 11, 14-21. https://doi.org/10.4236/eng.2019.111002

Received: December 7, 2018

Accepted: January 15, 2019

Published: January 18, 2019

Copyright $\odot 2019$ by author(s) and Scientific Research Publishing Inc. This work is licensed under the Creative Commons Attribution International License (CC BY 4.0).

http://creativecommons.org/licenses/by/4.0/

\begin{abstract}
Water is a basic normal asset for supporting the condition of life. Accessible water assets are feeling the squeeze because of expanding demand. Soon water, which we have depended upon to be accessible and an unconditional present of nature will turn into a rare product. Protection and conservation of water assets are desperately required. In many parts of Victoria, water supply to communities is limited. Rainwater harvesting systems can provide water at or near the point of demand. The systems can be owner and utility operated and managed. Rainwater collected using existing structures, i.e. rooftops, parking lots, playgrounds, parks, ponds, floodplains etc., has few negative environmental impacts compared to other technologies for water resources development. Rainwater is relatively clean and the quality is usually acceptable for many purposes with little or even no treatment. The physical and chemical properties of rainwater are usually superior to sources of groundwater that may have been subjected to contamination. The present study was intended to measure the rooftop rainwater harvesting potential using GIS techniques. The GIS examination utilized in this investigation was basically an efficient assessment of rooftop water collecting in the chose Wollert which is a suburb in Melbourne, Victoria. With the use of GIS it was conceivable to appraise the aggregate sum of water harvestable at the household level. It is very tedious work to assess the catchments available for rooftop rainwater harvesting. Here the roof surfaces are the catchments and GIS is employed to calculate the area of various types of roofs and their potential for planning for the area under study. As a result Eucalypt Estate Wollert has huge potential and can make above 179.11 litres water available per person per day throughout the year.
\end{abstract}

\section{Keywords}

Rainwater Harvesting, Potential, Measurement, Rooftop, GIS 


\section{Introduction}

Rainwater harvesting from rooftops of houses used to be an ancient practice in arid zones. It is a welcome practice in rural-urban areas especially where the rainfall is very scarce and irregular. The stress on groundwater has been increasing and rechargeable areas have been decreasing continuously. Roof water harvesting was practised, as a matter of necessity, mostly in the low rainfall areas of the country, having an annual average rainfall to Apr., $163.9 \mathrm{~mm}, 35.0$ day(s). The rainwater that falls on the surface/rooftop is channelled to bore wells or pits or new/old abandoned wells through small diameter pipes to recharge the underground water, which can be harvested to the extent of 55,000 litres per 100 sq.m areas per year [1].

Melbourne residents are encouraged to contain their daily water use to a maximum of 155 litres per day per person. However, this includes an allowance for garden watering. If we assume $10 \%$ of this is for the garden, then this becomes a working figure of 140 litres per day per person. A reasonable working annual figure on this basis is in the order of 50,000 litres per person. Note however that evaporative air conditioners on hot dry days can use large quantities of water (up to 25 litres per hour). Roof runoff into tanks provides high-quality water for drinking, hot water services, household cleaning and various veterinary and crop spraying purposes. It has been observed that modern constructed houses both in rural and urban areas provide no collection and storage facilities for roof water. Roof rainwater harvesting (RWH) is usually calculated using [2]. The increasing population growth and inefficient system of distribution of water by the Yarra Valley Water management authority has led to a seasonal scarcity of domestic water supply in practically all the rural and urban agglomerates. Traditionally, the rainwater collected from roofs was always stored in a sump. In modern days the roof water is stored in a sump or recharged into the local aquifer. This kind of practice directly used for recharging the local aquifer is becoming popular in urban and rural areas for mitigating water scarcity in semi-arid areas where annual rainfall is barely $500 \mathrm{~mm} \mathrm{[3].}$

The selected study area is Wollert, a northern suburb of Melbourne, where rooftop rainwater harvesting is an economical and ecologically sound means of replenishing groundwater. The present paper uses a GIS approach to assess the total area of catchment available for rainwater harvesting in Wollert and to calculate the amount of water, which could be really harvested for replenishing groundwater reserves [4].

\section{Study Area}

The study area is located in Wollert, $27 \mathrm{~km}$ north of Melbourne CBD and covers an area of $\sim 0.6 \mathrm{~km}^{2}$ (Figure 1). The region is managed by the City of Whittlesea Council, which assumes authority for land planning and development in the area. Yarra Valley Water manages the water supply and sanitation to the region and is responsible for managing and maintaining the region's water drainage infrastructure. 
The study area is situated within a residential pocket bounded by grazing land north of Lehmann's Road to the north, Binds Road to the east, Epping Road to the west and parklands to the south (Figure 1). Wollert is located within Melbourne's northern growth corridor, with plans to develop residential housing north of Lehmann's Road and a quarry to the northeast of the study area [5]. The topography is flat with a gentle downwards slope locally from the northeast and the southwest towards Findon Creek. Regionally there is a gentle topographic slope from north to south. The Findon Creek Catchment covers an area of $19.3 \mathrm{~km}^{2}$ and Findon Creek flows through the site in a southeasterly direction where it drains into Darebin Creek. Findon Creek's headwaters are located in Quarry Hills, approximately $2 \mathrm{~km}$ northwest of the study area. The flow regime of all rivers in the Darebin catchment is heavily modified and is ephemeral in nature [6].

The objective of this work is to assess the total volume of water collected through rainwater harvesting technologies with respect to different types of catchments, i.e. rooftops, roads and open spaces.

\section{GIS Data and Methodology}

The database and methodology were based on the review of literature by [7]. This is a Geographic Information System (GIS) based method to further the estimation of annual rainwater harvesting potential of the Wollert area. Google satellite images and current aerial photos were downloaded for the purpose and geo-referenced with the help of Arc GIS10.3. The different types of catchments included rooftops, roads and open spaces. Arc was included. GIS10.3 was also used to digitize all the different catchments using their respective topology. Finally, the area of catchments was calculated to find the total rainwater harvesting potential of the study area.

The selected areas of Google earth images were further combined and georeferenced in Arc GIS 10.3 versions. Then the georeferenced images were digitized in Arc GIS 10.3 and different entities were captured like rooftops, roads and streets and open spaces. The rooftops were captured as polygons. The roads are

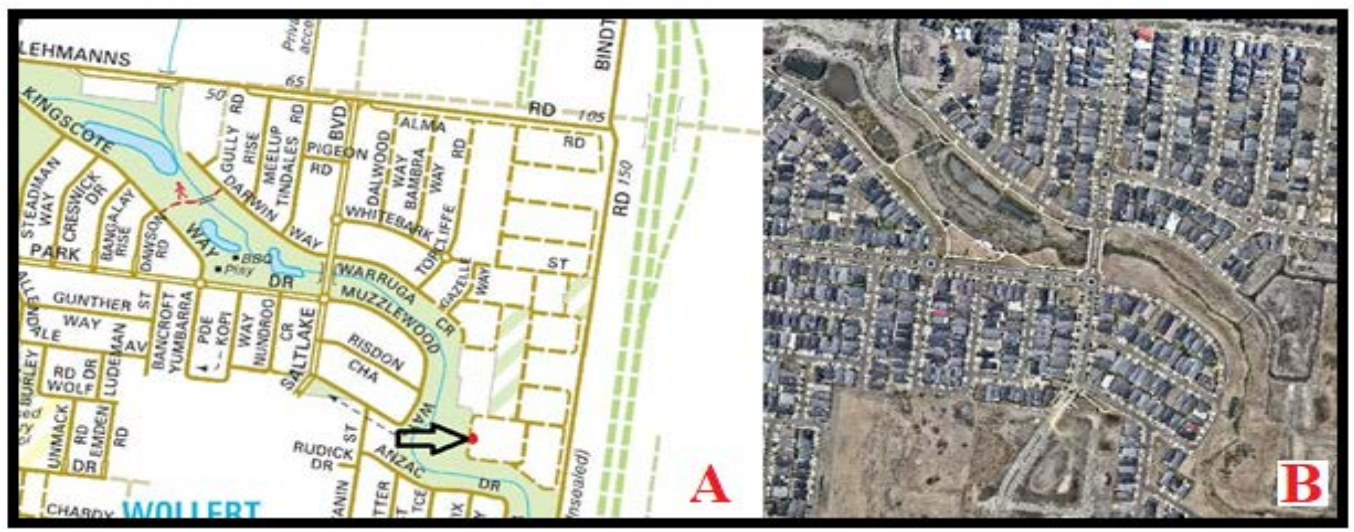

Figure 1. Study area (A) map of the study area (B) image from near map. 
not very suitable for rainwater harvesting and dilapidated and uneven. Rooftops were also ignored. In Wollert there are some conjoined housing plots these roofs were captured in the form of one big polygon consisting of all the connected houses. The roads were captured as arc while the open spaces or parks were again captured as polygons. After digitization, the map was further cleaned and the respective topology was created with the help of the same software. Then the area of all the catchments were calculated thus giving the total rainwater harvesting area available in the Wollert area.

The information was useful in calculating the annual rainwater harvesting potential of the area. The total study area of $610,222.99$ squre $\mathrm{m}$. 615 building rooftop households and 1845 persons was selected to predict rooftop rainwater harvesting potential where the average rainfall is $602.5 \mathrm{~mm}(0.6 \mathrm{~m})$ 2010-present (https://rainfall.willyweather.com.au/vic/melbourne/wollert.html). Water demand is 166 litres per person per day. Figure 2 and Figure 3 show that residential water

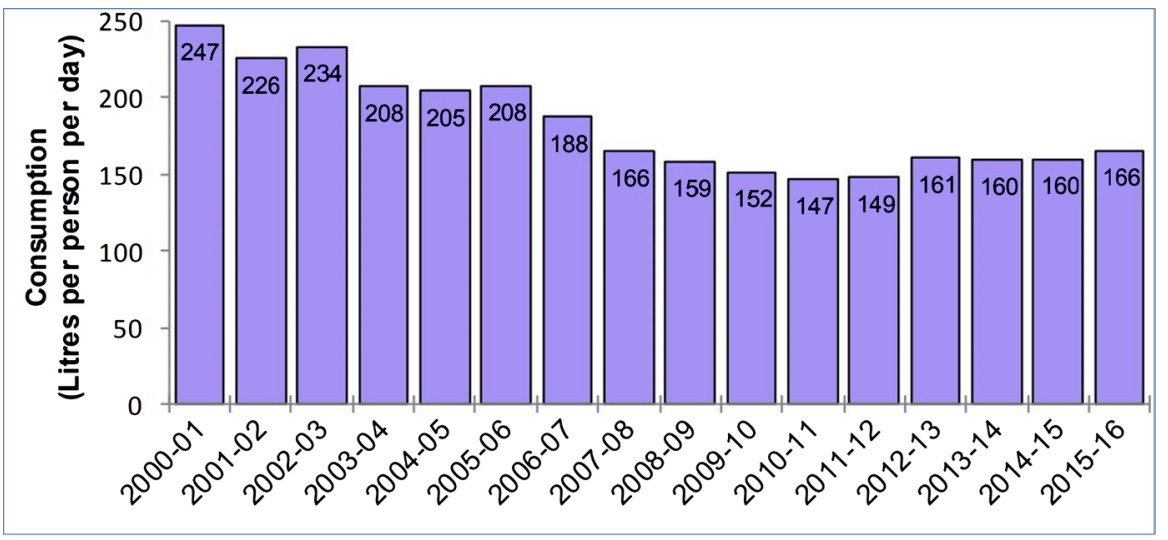

Figure 2. Residential water use in Melbourne (litres per person day).
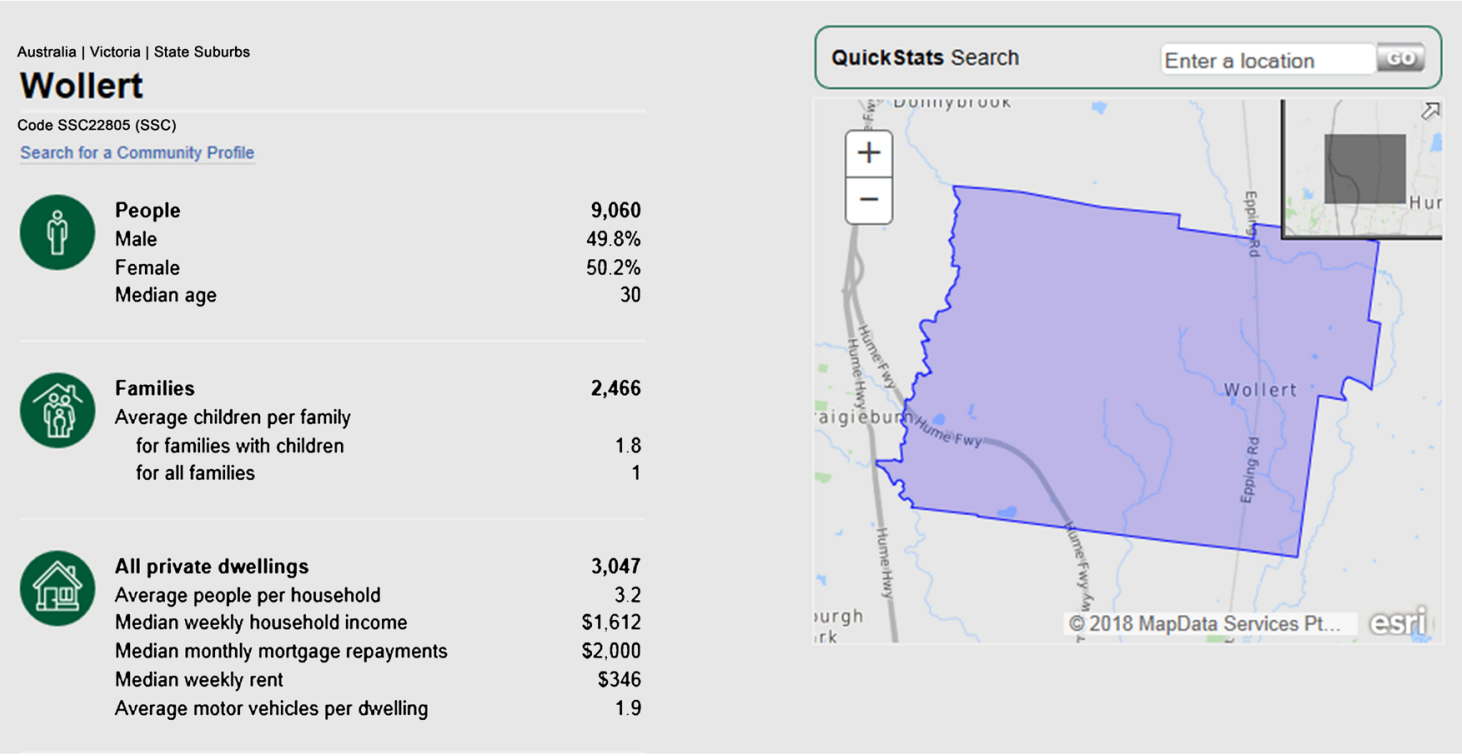

Figure 3. Inhabitants characteristics in Eucalypt Estate Wollert (Source:

http://www.censusdata.abs.gov.au/census_services/getproduct/census/2016/quickstat/SSC22805). 
use on a per person basis rose to 166 litres per person per day in 2015-16 due, in part, to the hot dry conditions-an increase of 6 litres per person per day from the 2014-15 level of 160 litres per person per day.

\section{Results and Discussion}

The area of the catchments was calculated with the help of Arc GIS software. Based on various factors, the annual rainwater harvesting potential (ARHP) of the study region is estimated by using the following formula given by [8]:

Area of Catchments in sq. $m \times$ Rainfall in Metres $\times$ Runoff Coefficient...

\section{Runoff Coefficient}

Runoff coefficient is the factor, which accounts for the fact that not all the rain falling on a catchment has collected, some rainfall is lost from the catchment by evaporation and some is retained by the surface itself.

\section{Annual Rainwater Harvesting Potential from Rooftops}

$$
\text { Brick Pavement }=146311.87 \times 0.6 \times 0.7=61450.9854
$$

Total Potential from Rooftop $=61450.9854$ cubic metres (61450985.4 litres). So the total rainwater that would be collected from rooftops was calculated to be 61450985.4 litres (Figure 4).

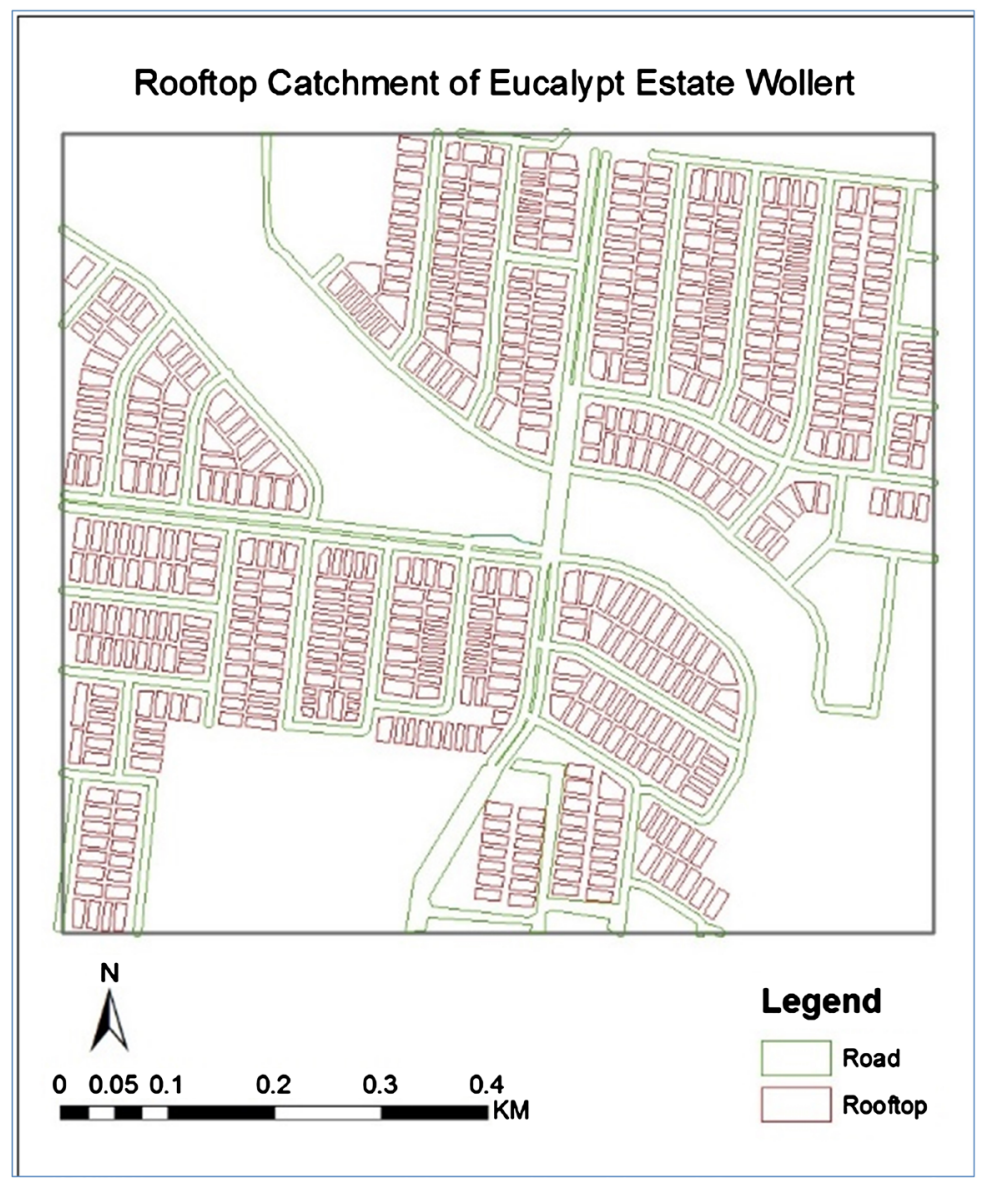

Figure 4. Roof top catchments of Eucalypt Estate Wollert. 


\section{Annual Rainwater Harvesting Potential from Road Catchments $80785.69 \times 0.4 \times 0.6=19388.5656$ cu.m. $(19388565.6$ litres $)$}

The roads between the houses and main roads in Eucalypt Estate Wollert are made up of concrete. The run-off coefficients of roads were also taken as 0.4 [3] [4], so the total rainwater that could be collected from roads was found to be 19388565.6 litres (Figure 5 and Figure 6).

$$
220998.88 \times 0.3 \times 0.6=39779.7984 \text { cu.m. }(39779798.4 \text { litres })
$$

The average run-off coefficients of open spaces were taken as 0.3 [3] [4]. So the total rainwater that could be collected from open spaces was found to be 39779798.4 litres.

Grand Total of Annual Rainwater Harvesting Potential for All the Source Catchments as:

$61450985.4+19388565.6+39779798.4=120619349.4$ litres

Annual per person water available $=120619349.4 / 1845$ persons $=65376.34$ litres

Per person per day water available $=65376.34 / 365$ days $=179.11$ litres

Daily water availability in only dry days $=65376.34 / 243$ days ( 8 months or 243 days)

$$
=269.03 \text { litres }
$$

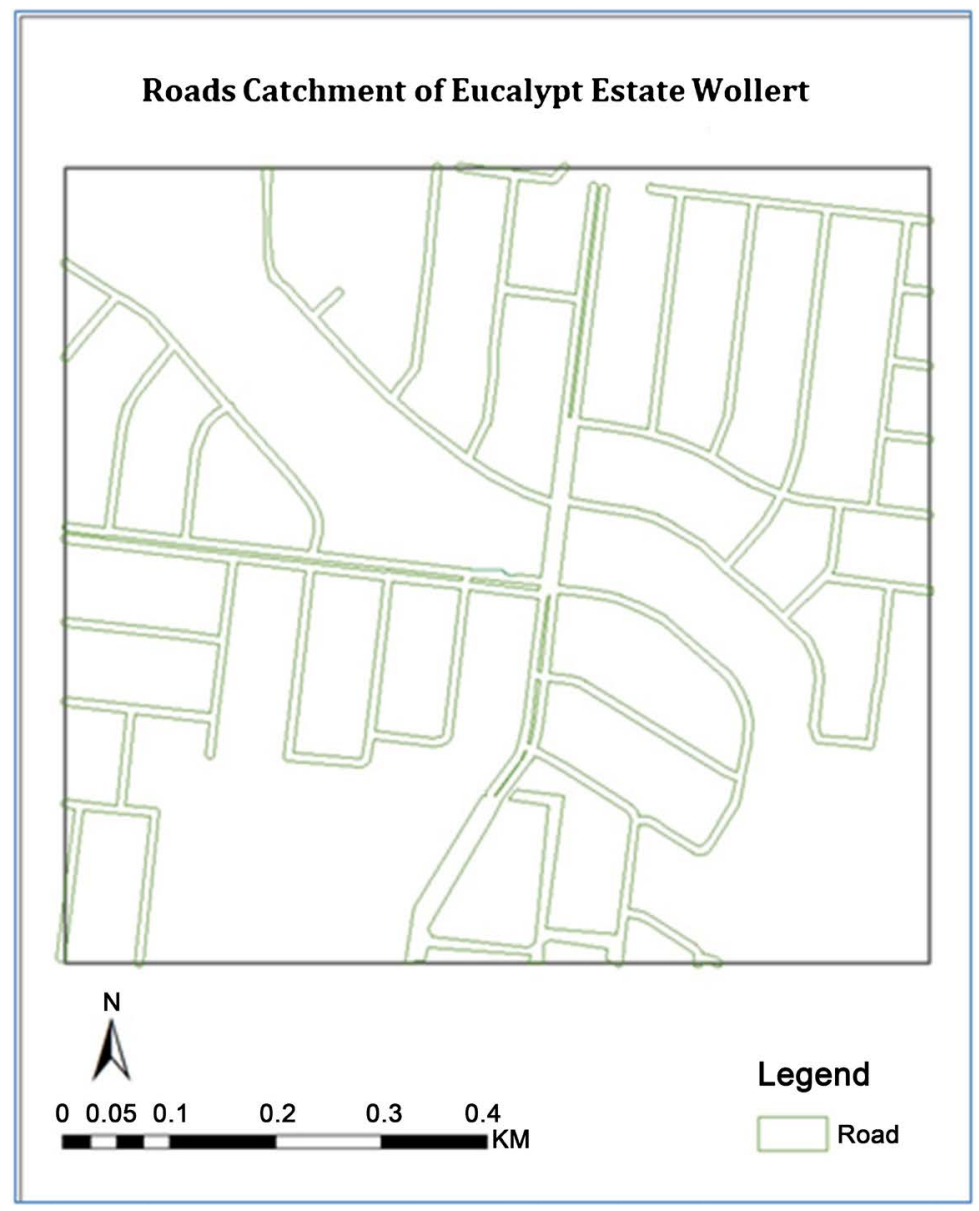

Figure 5. Annual rainwater harvesting potential from roads catchments. 


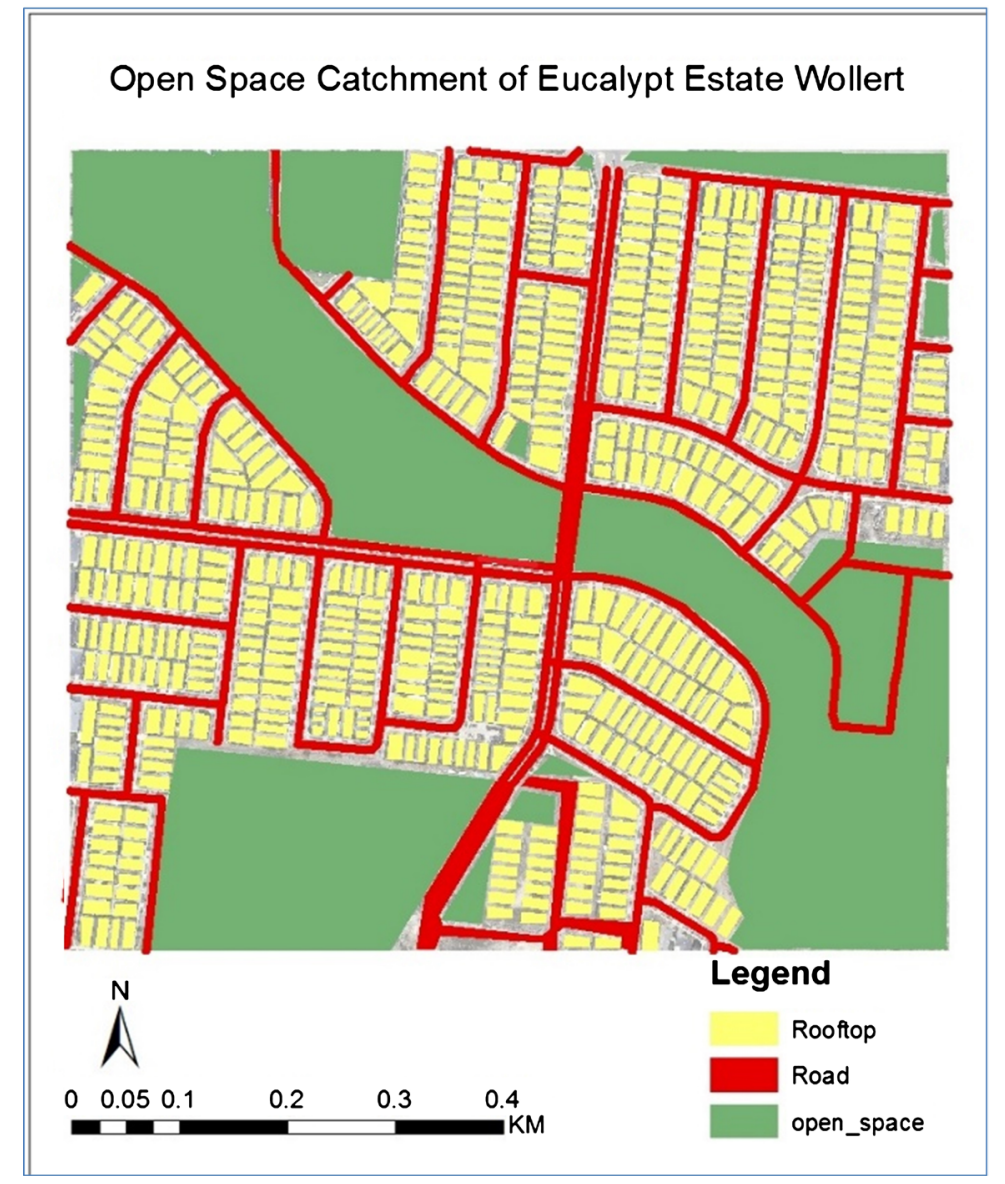

Figure 6. Open space catchments of Eucalypt Estate Wollert.

\section{Conclusion}

It is scientifically proved that, through this rooftop rainwater harvesting method, water scarcity can be minimized to a certain extent and water collected can be used for drinking and domestic purposes. Thus it can be inferred that Eucalypt Estate Wollert has huge potential and can make above 179.11 litres water available per person per day throughout the year. It could be more than 269.03 litres per day per person if computed only for 245 dry days. From this the 180 litres of water per person per day are easily met as the entire area can collect 120619349.4 litres of water per annum. Melbourne Residential water use on a per person basis rose to 166 litres per person per day in 2015-16.

\section{Conflicts of Interest}

The authors declare no conflicts of interest regarding the publication of this paper.

\section{References}

[1] Athavale, R.N., Rangarajan, R. and Muralidharan, D. (1998) Influx and Efflux of Moisture in a Desert Soil during a 1 Year Period. Water Resources Research, 34, 2871-2877. https://doi.org/10.1029/98WR01836 
[2] Ennenbach, M., Concha Larrauri, P. and Lall, U. (2018) County-Scale Rainwater Harvesting Feasibility in the United States: Climate, Collection Area, Density, and Reuse Considerations. JAWRA Journal of the American Water Resources Association, 54, 255-274. https://doi.org/10.1111/1752-1688.12607

[3] Strock, J.S., Dell, C.J. and Schmidt, J.P. (2007) Managing Natural Processes in Drainage Ditches for Nonpoint Source Nitrogen Control. Special Section: Drainage Ditches, Report. Journal of Soil and Water Conservation, 62, 197-206.

[4] Toulmin, C. and Arnold, P. (1987) Rainwater Harvesting: The Collection of Rainfall and Runoff in Rural Areas. Book Review, Development Policy Review, 5, 447.

[5] The City of Whittlesea and Metropolitan Planning Authority (2015) Guidelines for Urban Development.

https://www.whittlesea.vic.gov.au/media/1905/manual-accessible.pdf

[6] Davis, G. and Francis J. (2011) Inquiry into Local Economic Development Initiatives in Victoria. Report Submitted to the Parliament of Victoria.

https://www.parliament.vic.gov.au/images/stories/committees/edic/local_economic _initiatives/subs/48_-_Whittlesea_City_Council_Redacted.pdf

[7] Shailaja, G., Kadam, A., Gupta, G., Umrikar, B., Umrikar, B.N. and Pawar, N.J. (2018) Integrated Geophysical, Geospatial and Multiple-Criteria Decision Analysis Techniques for Delineation of Groundwater Potential Zones in a semi-Arid Hard-Rock Aquifer in Maharashtra, India. Hydrogeology Journal, 26, 1-16.

[8] Adham, A., Sayl, K., Abed, R., Abdeladhim, M., Wesseling, J., Riksen, M., Fleskens, L., Karim, U. and Ritsema, C.J. (2018) A GIS-Based Approach for Identifying Potential Sites for Harvesting Rainwater in the Western Desert of Iraq. International Soil and Water Conservation Research, 6, 297-304.

https://doi.org/10.1016/j.iswcr.2018.07.003 